\title{
THE ROLE OF PROPHECY IN THE GROWTH AND EXPANSION OF THE SYNAGOGUE CHURCH OF ALL NATIONS
}

\author{
James N Amanze \\ Visiting Prof, Dept of Biblical and Ancient Studies \\ University of South Africa
}

\begin{abstract}
This article examines the role of prophecy in the growth and expansion of the Synagogue Church of All Nations (SCOAN) in Nigeria. The article argues that the Church in Africa is growing in leaps and bounds - unprecedented in the history of Christianity since its introduction in the $19^{\text {th }}$ century. This growth and development, however, is taking place mainly in the New Religious Movements particularly the Pentecostal-charismatic Churches because of their emphasis on the prophetic ministry of the Church characterised by performance of healing miracles and predicting the future. A good example is the Synagogue Church of All Nations (SCOAN) of Prophet TB Joshua. Taking this as a case study, the article argues that Prophet Joshua's success and that of his church is found in the fact that they have taken the message of the prophets very seriously and that the modus operandi and modus vivendi of Joshua and SCOAN are reminiscent of the prophetic traditions of Elijah and Elisha in ancient Israel.
\end{abstract}

Key Words: Divination; Healing; Prophecy; Synagogue Church of All Nations; Typology

\section{Introduction}

One of the most exciting and interesting developments in the church in Africa today is the spectacular popularity of the Synagogue Church of All Nations (SCOAN), which was founded by TB Joshua in 1987. This article examines the factors that have contributed to the unprecedented growth of this church compared to the stagnation of the mainline churches in Africa south of the Sahara. The argument is that the growth of SCOAN is based on Prophet Joshua's successes in healing and his ability to 'accurately' predict future events. These are taken by his followers as irrefutable evidence that he is indeed a man of God. The article begins by examining the role of prophecy in Hebrew tradition as experienced in the Hebrew Bible and then links it with the nature of prophecy found in SCOAN today which is reminiscent of the prophetic tradition of $9^{\text {th }}$ century prophets in Israel. Particular reference is made to prophets Elijah and Elisha because of their magic-like miracles of healing and their ability to know things that were happening or done in secret.

The gist of the article is that the $9^{\text {th }}$ century BC prophecy, which consisted of the combination of magical performances and the ability to read 'accurately' what was going on in the political, social, religious and economic systems of the time both within and outside Israel, has much in common with the prophecy that is found in the Synagogue Church of All Nations today. This type of prophecy seems to be the driving force, which is attracting many people to seek personal, spiritual, economic and political help from SCOAN and Prophet TB Joshua in Lagos, Nigeria. This article relies heavily on Internet sources because 
the author has never travelled to Nigeria to collect stories locally regarding Prophet Joshua's life and work and to observe what is going on in the SCOAN itself. Again, oral sources in Botswana where I live and work are scanty and people who have been to SCOAN do not volunteer to divulge information. This, however, has not deterred me from making a tentative comparison between the type of prophecy that is found in the SCOAN and that of the $9^{\text {th }}$ century BC prophets in Ancient Israel.

\section{The Resurgence of Christianity in Africa in the $21^{\text {st }}$ Century}

The $21^{\text {st }}$ century has experienced an unprecedented upsurge of Christianity in Africa south of the Sahara in the history of its existence since its reintroduction in the $19^{\text {th }}$ century. This phenomenon seems unstoppable. It has made Africa almost the hub of Christianity in the world and this is a compliment to the African people. GJ MacDonald in his article titled "Study: Christianity grows exponentially in Africa," has indicated that with 2.18 billion adherents, Christianity has become a truly global religion. According to MacDonald, over the past century the rapid growth in developing countries has offset the decline of Christianity in traditional strongholds particularly in Europe. Recent major research findings have observed that there have been major shifts in Christian populations since 1910 when two-thirds of the world's Christian population lived in Europe. In recent years it has been found that now only one in four Christians live in Europe. Most of the rest are distributed across the Americas (37\%); sub-Saharan Africa (24\%) and the Asia-Pacific region $(13 \%)$.

It has further been observed that although Christianity traces its beginnings to the Middle East and North Africa, only 4\% of residents in these regions claim to be Christians. Meanwhile, Christianity has grown tremendously in sub-Saharan Africa, from just $9 \%$ of the population in 1910 to $63 \%$ of the population today. It has been noted that as a result of historic missionary activity and indigenous Christian movements by Africans, there has been this change from about one in 10 (sub-Saharan Africans) identifying themselves as Christians in 1910 to about six in 10 doing so today. ${ }^{1}$

Interestingly enough, recent research shows that much of this growth is taking place in the New Religious Movements, especially in the new Pentecostal-charismatic churches rather than in the Mainline Churches because of their ability to perform 'miracles' and 'predict' future events which, apparently, come to pass. A good example of a country in sub-Saharan Africa, where Christianity is growing in leaps and bounds, is Nigeria, a home to more than 80 million Christians ${ }^{2}$ and also the home of the Synagogue Church of All Nations (SCOAN) which is the subject matter of this article.

It appears that the new Pentecostal-charismatic churches have a good grasp of the African psyche whose main concern is to overcome the powers of evil, which are considered to be the source of all kinds of diseases, poverty, misfortunes, bad luck, human suffering and ultimately death. Therefore, there appears to be an insatiable need among Africans to have the power that can enable them to manipulate both natural and supernatural powers in order to achieve their objectives in life. Because of this psychological need to manipulate natural and supernatural phenomena to fulfil one's aspirations, many African people in sub-Saharan Africa are readily attracted and respond positively to the

http://www,usatoday.com/news/religion/story/2, accessed on 23/9/2012.

2 http://www,usatoday.com/news/religion/story/2, accessed on 23/9/2012. 
new Pentecostal-charismatic Churches where they are promised abundant health and wealth amidst poverty, diseases, deprivation, suffering and death. This accounts, to a large extent, for the fast and amazing growth of the Pentecostal-charismatic churches in Africa today.

\section{Theoretical Framework: Fohrer's Typology of Prophecy in Israel}

In conceiving and writing this article I have decided to use Georg Fohrer's typology of prophecy in Ancient Israel. This is because this theoretical framework fits in well with the material at hand and the purpose and objectives of this article. But before I discuss Fohrer'stypology of prophecy, as discussed in his book titled History of Israelite Religion, it is important first and foremost that we understand the nature and functions of prophets in Hebrew society. It is also important that we understand the nature of the message that they delivered to their people.

RN Whybray has observed that it is not possible to give a comprehensive definition of an Israelite prophet since the persons conventionally included in this category manifested a diversity of character and function. Consequently, a prophet or prophets are referred to by a number of terms that in some texts are used interchangeably. However, Whybray has given us a working definition of a prophet. According to Whybray in ancient Israel prophets were men or women believed to be recipients of divine messages through audition, vision or dream, and they passed on such messages to others by means of speech or symbolic action. Their messages were addressed to individuals, particular groups of Israelites, the whole nation or even foreign powers. ${ }^{3}$ Whybray has further indicated that the messages of the prophets were frequently not solicited and were delivered under divine compulsion. However, there were occasions when prophets were consulted by people who wished to know whether or not the prophets had a message for them from God. ${ }^{4}$

Whybray has pointed out that prophets in ancient Israel had different functions. These included, among others, rebuking kings for their immoral behaviour (2 Sam.12:1-12; 1 Kings 18:15-19; 1 Kings 21:17-24); helping people to discover lost property ( 1 Sam.9:120); acting as military advisors to the king (1 Kings 22:1-28; 2 Kings 3:11-19); fomenting coup d'états by deposing one king and choosing and consecrating another (2 Kings 9:1-13); acting as miracle workers (2 Kings 6:1-7); healing the sick (2 Kings 5:1-14); predicting the future (1 Kings 17:1) and raising the dead (1 Kings 17:17-24; 2 Kings 4:8-37). ${ }^{5}$

Michael Ramsey has noted that, by and large, the prophets claimed to be the mouthpieces of Yahweh and that they spoke under the inspiration of the Spirit of Yahweh who was held to be the source of many kinds of extraordinary strengths and skills. The prophets were conscious of a divine command to speak on Yahweh's behalf and of divine guidance as to what they should say. According to Ramsey, the prophets spoke under overwhelming divine constraint in such a way that their mind and speech were brought into relation with Yahweh's word. ${ }^{6}$

As regards the message of the prophets, Ramsey indicates that it was one of the mediums of communication or speech of Yahweh to the people of Israel. The prophets

RN Whybray, “Prophets” in Bruce M Metzger \& Michael D Coogan (eds.), The Oxford Companion to the Bible. Oxford: Oxford University Press, 1993:621.

Whybray, "Prophets”, 621.

Whybray, “Prophets”, 621.

6 Michael Ramsey, “The authority of the Bible” in Matthew Black \& HH Rowley (eds.), Peake's Commentary on the Bible. Middlesex: Thomas Nelson \& Sons, 1977:2. 
claimed to speak with Yahweh's authority and this is why their utterances were frequently introduced with the formula "Thus says Yahweh.” This is also why the people who edited their prophecies in writing described how the word of Yahweh came to them. In this context, according to Ramsey, the term "word of Yahweh” has special significance for the understanding of the prophetic message. Ramsey notes further that the criteria of authenticity of the word of Yahweh thus spoken were found not in the particular media of communication, whether dream or ecstasy, but in the fulfilment of the things which the prophet declared would happen. Such fulfilment was evidence that the word of God had truly come to the prophet. ${ }^{7}$

Georg Fohrer has observed that in ancient Israel there were two forms of prophecy which corresponded to two types of religious backgrounds, namely nomadic religion and religion of the settled area. The corresponding prophets were the 'seer' and the nabhi. Fohrer points out that in the life of nomads of the ancient Near East the figure of the seer played an important role. According to Fohrer, people who functioned as 'seers' proclaimed divine instructions primarily on the basis of dreams and premonitions. ${ }^{8}$ Fohrer has noted that in the early nomadic life the activities of the seer coincided, to a certain extent, with that of a priest, magician, and clan leader and was normally held to be inspired by God. Fohrer has noted that the seer's primary contact with the other, higher world was through the sense of vision, in which case hearing played a lesser role. Oracles were usually based on what came into view and what the seer observed (see Numb. 22-24). For the seer to function he had to open his soul and his spirit, in order to receive the first impressions given to him by outward appearances. ${ }^{9}$

It appears that in the history of the people of Israel, the $9^{\text {th }}$ century BC prophets, that is, Elijah and Elisha represented, to a certain extent, this class of prophets. The aforementioned two prophets, apart from their core duty of defending Yahweh in opposition to religious apostasy and to the authority of kings who failed to uphold the cause of Yahweh or flouted his moral demands, also performed a number of miracles which seem to have made them somewhat popular. Although the miracles that are associated with them may sound legendary, they seem to represent popular views of the prophets of their time. ${ }^{10}$

Fohrer has indicated that another type of prophecy had its roots in the settled area of the ancient Near East. This type of prophet is associated with ecstatic prophets at sanctuaries or royal courts. They were best known as nabhis. According to Fohrer, Jewish prophecy reached its summit in the prophetic works of the $8^{\text {th }}$ century prophets such as Isaiah, Jeremiah, Ezekiel, Amos, Hosea and others. ${ }^{11} \mathrm{SH}$ Hooke has noted that the autobiographical elements which have been preserved among their oracles, show that all these men had passed through a profound experience of God, which gave them a sense of mission and set them consciously apart from the official class of prophets of their day. ${ }^{12}$

According to Hooke, these men did not regard themselves as innovators but as recalling Israel to standards of private and public conduct which reached back to the time of the

Ramsey, “The authority of the Bible”, 1-2.

Georg Fohrer, History of Israelite Religion, London: SPCK, 1972:224.

Georg Fohrer, History of Israelite Religion, London: SPCK, 1972:224.

Whybray, "Prophets”, 621.

Fohrer, History of Israelite Religion, 224.

12 SH Hooke, "The religious institutions of Israel” in Matthew Black and HH Rowley, Peake's Commentary on the Bible, Melbourne: Thomas Nelson \& Sons, 1962:148. 
covenant mediated by Moses. One of their chief characteristics is that they were the most trenchant critics of the religious institutions and people of their times, princes, priests and even other prophets. ${ }^{13}$ By most accounts, these prophets placed a great deal of emphasis not so much on performing miracles or predicting the future, but denouncing the public morality of their people.

Whybray has intimated that though the prophets of the 8th and 7th centuries BCE stood for the same principles as their predecessors, their prophecy was radically different from that of $9^{\text {th }}$ century BC in two decisive ways. In the first instance, the 8 th and $7^{\text {th }}$ century BC prophets addressed themselves not only to kings and other individuals and particular groups but also the whole people. Secondly, they were the first to prophesy the destruction of the entire nation as a punishment for its sins. According to Whybray, this prophecy of national disaster was the main feature of the message of the prophets of the 8th century BC BCE such as Hosea, Amos, Isaiah, Micah, Jeremiah and Ezekiel and it was presented as avoidable only through repentance of sins. It should be noted that prophets who delivered unpalatable messages like this faced great difficulties not only in terms of finding acceptance as authentic messengers of Yahweh but they were also liable to suffer humiliation and even threats to their lives (Amos 7:10-13; Jer. 26:7-9). ${ }^{14}$

This article argues that TB Joshua's prophetic ministry seems to be similar to that of the $9^{\text {th }}$ century BC prophets in ancient Israel, particularly that of prophets Elijah and Elisha. This is because their ministries resemble, to a large extent, the prophetic ministry of TB Joshua today. As we shall see below, Elijah's and Elisha's prophecies were full of miracles of different types and were also full of predictions about many things that came to pass during their ministries. This phenomenon of prediction and fulfilment tended to make people believe that they were indeed men of God. This may have made them popular among the people of their time. This is exactly what is happening in the case of Prophet TB Joshua today. He is well known for his magic-like miracles of healing.

It is also claimed that many of his predictions of what will happen in the future and knowing what is happening in secret have been fulfilled. On the basis of this, many people in Africa south of the Sahara believe that he is truly a man of God. In this regard, Fohrer's theoretical framework of dual typology of prophecy is an ideal tool to analyse the work of the Synagogue Church of All Nations, whose fame attracts many people from many countries in sub-Saharan Africa who flock to Lagos, Nigeria, for healing and to consult the prophet on whether or not he has received a message from God for them.

13 Hooke, "The religious institutions of Israel”, 48.

14 Whybray, "Prophets”, 622. 


\section{The Origin, Development and Expansion of SCOAN}

Having discussed the theoretical framework on which this article is based, I now shall discuss the origin and development of the Synagogue Church of All Nations (SCOAN) which has today become a household name because of the prophetic activities of Prophet TB Joshua. But before I proceed to talk about the Church it is important for us to understand the founder and leader of this church.

\section{Prophet Joshua: Personal History}

The personal history of TB Joshua is obscure. According to one of my respondents, AE Arua, Joshua's early childhood and infancy is shrouded in mystery. There are no independent sources offering a detailed account of his birth, education, adult life and how he was called into the ministry of prophecy. As a result, a great number of Nigerians are sceptical about him as a person and the reliability and validity of his ministry is questioned. This view is the official position of the Christian Association of Nigeria, an ecumenical organisation, which until now has not yet granted membership to SCOAN. ${ }^{15}$

However, having said that, SCOAN's official website states that Prophet Joshua was born on 12 June 1963 in the small village of Arigidi in Akoko, Ondo State, Nigeria. It is claimed that his birth, like of many who claim to be prophets, was surrounded by unusual occurrences. For example, it is held that the pregnancy period of his mother was rather extraordinary. He remained in the womb for 15 months before he was born. It is also claimed that his birth was predicted 100 years earlier when it was prophesied that a young man would emerge from the poor Oosin quarters and that God would use him mightily. ${ }^{16}$ It is also held that when he was only three days old, another unusual event occurred. A large stone crashed through the roof of his house. It missed the baby by mere inches. This incident led his mother to name him 'Temitope' which means "What you (God) have done for me is worthy of thanks." ${ }^{17}$ Temitope attended St Stephen's Anglican Primary school at Arigidi. He eventually became the leader of the student Christian Fellowship there. Although he was the smallest person in the class, he led the prayers during the school devotions and as a result he was known as 'a small pastor'. ${ }^{18}$ However, due to poverty Joshua did not complete secondary education. ${ }^{19}$

Prophet Joshua's account of his call is presented to us in the pattern of the call of the Old Testament prophets. According to Joshua himself, when he was called to be a prophet he received a Bible which entered into his heart, and a small crucifix. He also heard a voice which said "I am your God; I am giving you a divine commission to go and carry out the work of the heavenly Father". ${ }^{20}$ The voice also promised him that God would show him wonderful ways and that God would reveal himself to him in teaching, preaching, performing miracles, and signs and wonders for the salvation of souls. ${ }^{21}$ He holds that the Bible that entered his heart symbolised the Holy Spirit. He believes that God's word is

\footnotetext{
Interview with AE Arua, University of Botswana, Gaborone, 13/11/2013.

http://scoan.org/about/prophet-joshua/biography-accessed on 6/9/2012.

http://scoan.org/about/prophet-joshua/biography-accessed on 6/9/2012.

http://scoan.org/about/prophet-joshua/biography-accessed on 6/9/2012.

http://.scoan.org/about /prophettb-joshua/biography- accessed on 6/9/2012.

http://scoan.org/about/prophet-joshua/biography-accessed on 6/9/2012.

21 http://scoan.org/about/prophettb-joshua/biography accessed on 6/9/2012.
} 
spirit and life. ${ }^{22}$ Another version of his calling states that in 1989, Prophet Joshua fasted and prayed for 40 days and 40 nights during which he had a heavenly vision in which he received divine anointing and a covenant from God to start his ministry. ${ }^{23}$ It appears to me that this second version of his call is a deliberate theological construct by SCOAN to place Prophet Joshua along the line of Jesus of Nazareth who before his ministry fasted for 40 days and 40 nights in the wilderness (see Matthew 4:1-2).

Despite this personal testimony of his call, Prophet Joshua has not escaped criticism concerning the authenticity of his ministry. It is argued, in the first instance, that that he is a shaman, therefore the source of his ministry cannot be Jesus Christ and the Holy Spirit. Coupled with this, it is contended that his character and work are not supported by anything that we find in the Bible and that his signs and wonders do not prove that it is God who is working in him. In addition to this, it has been observed that the source of his powers of healing is demonic and that his doctrine is false and benefits only Satan. Those who challenge his call assert that he uses occult techniques in the name of Jesus Christ and that many of his 'miracles' are faked. Many believe that during the performance of his miracles he uses evil powers such as witchcraft or water spirits to achieve his ends. Moreover, it is argued that he teaches heresy and therefore he is a heretic running around confusing people. To crown it all it is noted that he has turned Nigeria into the destination for the spiritually confused. ${ }^{24}$ Be that as it may, it is not our intention here to enter into a lengthy debate on this matter but merely to highlight that Prophet Joshua's prophetic ministry is surrounded by controversy both at home and abroad.

It should be noted here that despite the above criticism, one of Prophet Joshua's strengths in his ministry, which is beyond criticism, is his philanthropic work. It is reported that in recent years he has donated over 20 million US dollars to causes in education, health care and rehabilitation programmes for former Niger Delta militants. ${ }^{25}$ In this regard, one of my respondents told me a story of how two young men from Zambia travelled by land all the way to Nigeria to seek help from Prophet Joshua for them to be able to embark on further studies. When they arrived at SCOAN, Joshua gave them scholarships that could enable them to pursue their academic studies to the highest level possible. ${ }^{26}$ Prophet Joshua claims that he does this because he realises that there are millions of people around him who need financial help. He believes that he will offend God if he chooses to save his excess money in a bank account rather than giving it to those who need it most. ${ }^{27}$

\section{SCOAN: From Humble Beginnings to an International Church}

According to SCOAN's official website, Prophet Joshua established his church in 1987 together with a group of eight people. Their first meeting was held in a humble shelter in a squalid, swampy jungle in the location of Agodo-Egbe in Lagos, Nigeria. The purpose of their meeting, it is claimed, was to start a mission which would bring salvation to the world.

\footnotetext{
22 http://scoan.org/about/prophettb-joshua/biography accessed on 6/9/2012.

23 http://articles.onlinenigeria.com/nigerian-churches/4283-synagogue-church-of-all-nati, accessed on 14/11/2013.

24 http://www.deceptioninthechurch.com/tbjoshua.html; accessed on 13/11/2013.

25 The richest churches in Nigeria, http://www.forbes.com/sites/mfonobongnsehe/2011/06/07/the accessed on 10/10/2012.

26 Personal communication with IB Ikpe, University of Botswana, Gaborone, Botswana.

27 http://www.deceptioninthechurch .com/tbjoshua.html, accessed on 13/11/2013.
} 
Within a short space of time Joshua began to show signs that he was not an ordinary pastor, preaching ordinary words and doing ordinary things. It became evident to many people that God was calling him to do greater things than an ordinary pastor does. Miraculous occurrences began to take place. It is claimed that the lame began to walk, cancer patients who had given up all hope, were lifted from their despair and desperate situations were turned into scenes of life, joy and peace. ${ }^{28}$

On the instructions of what is believed to be the Holy Spirit, Joshua named his church Synagogue Church of All Nations (SCOAN) of which he is the General Overseer. With the passing of time, people began to attend his church in large numbers and as a result the Synagogue moved to a large expanse of land in Ikotun-Egbe on the outskirts of Lagos. Thousands began to flock to the services as they heard about the miraculous events taking place there. As people became aware of the presence of the church in Lagos, people of every colour, culture, and creed began to travel from all quarters of the world to witness the power of God in SCOAN. Countless testimonies continued to flood in as Joshua continued to heal all manner of diseases in the name of Jesus. This boosted Joshua's fame far and wide, not only in Nigeria, but also in surrounding countries. ${ }^{29}$

With the numerical growth of the church in mind, there was a felt need to build a cathedral. This was done within a short space of time, marking the beginning of unprecedented expansion of the church to international proportions. Joshua has continued his ministry of healing, prophecy, deliverance, blessing and salvation. It is claimed that healings of HIV-AIDS, cancer, paralysis and of many other diseases occur every week. Sunday services are broadcast to millions of people around the globe through Emmanuel TV and the cathedral is always filled to capacity with worshippers from across Nigeria and the world. ${ }^{30}$ It should be noted that from very humble beginnings, SCOAN today boasts a large following and Prophet Joshua is considered as one of the richest men in Nigeria. His cathedral accommodates more than 15000 worshippers. The church currently has branches in Austria, Ghana, United Kingdom, South Africa, Gabon, Greece and United Kingdom.

\section{SCOAN: The Desired Destination of People Seeking Healing and Messages from God}

It is important at this point to note that Joshua's ministry does not only attract national and regional admirers but also many international visitors from every quarter of the African continent. His miracles and, more importantly, his prophecies, such as those performed by Elijah and Elisha in the $9^{\text {th }}$ century BC in ancient Israel, have made people believe that he is indeed a man of God and that he has divine powers to accomplish things that other people cannot. His headquarters in Nigeria is visited by many people from Botswana, Zambia, Malawi, South Africa, Zimbabwe, Ghana, Cameroon to name but a few. ${ }^{31}$

The popularity of Prophet Joshua is not limited to common people in the abovementioned countries. In recent years many African leaders have been flocking to Lagos,

\footnotetext{
28 http://www.scoan.org/about/history, accessed on 11/8/2012.

29 http://www.scoan.org/about/history, accessed on 11/8/2012.

30 http://www.scoan.org/about/history, accessed on 11/8/2012.

31 http://distanceisnotbarrier.wordpress.com 2011 accessed on 6/9/2012. Information also based on personal experience of actual people who have gone to consult TB Joshua from Botswana. Information also based on personal communication with Dr Ikpe at the University of Botswana, 23/2/2013; and Bishop Brighton Malasa from Malawi, 25/2/2013.
} 
Nigeria, for spiritual healing and deliverance. The church also attracts crowds from all over the world because of the amazing miracles performed by Joshua. Sources at hand show that Joshua began to attract African leaders to SCOAN in the early 1990s when he was visited by the then Governor General of the Republic of Bahamas. It is reported that in 1999, Patrick Chiluba, the former Zambian President took part in an act of worship in SCOAN. Among African leaders, the late President of Ghana John Atta Mills was considered the closest friend of Pastor Joshua. It is held that President Mills' unwavering faith in Prophet Joshua was inspired by Joshua's accurate prediction of the course and outcome of the elections that brought Mills to power in Ghana in 2009. ${ }^{32}$

Apart from these leaders, other African leaders that have visited Joshua include the Zulu King Goodwill Zwelithini and Limpopo King Koshi Kgabo of South Africa; President Omar Bongo of Gabon; Pascal Lissouba of Congo Brazzaville; former Liberian warlord Yomie Johnson; Joyce Banda, now President of Malawi; former President of the Central Africa Republic, Andre Kolingba; former Zimbabwean Prime Minister, Morgan Tsvangarai and South Africa's Winnie Madikizela-Mandela. It is held that the list of dignitaries to SCOAN is not confined to Africa. For instance, other leaders, who have visited SCOAN, include Rev. Tay Cheng Kee, founder of the Bethesda Cathedral in Singapore and Ralph Beimer, a former US judge. ${ }^{33}$ As a result of the growing popularity of SCOAN, African leaders now lead crowds of pilgrims to Nigeria in search of salvation and healing. ${ }^{34}$

\section{Factors that Attract People to SCOAN}

\section{Healings}

It is important to point out here that by most accounts, Joshua's ministry has grown tremendously as a result of his inexplicable powers of healing, thereby constituting another source of controversy as a result of lack of scientific evidence. Healings of prominent people have been recorded. These include the healing of Princess Sibusile, the daughter of King Goodwill Zwelithini (South Africa) who was healed after many failed attempts in hospital using Western medicine. She has since devoted her life to the service of God as a worker at SCOAN. ${ }^{35}$ There are many stories that describe how Joshua healed people suffering from a variety of diseases.

One such story surrounds the healing of a certain Mrs Comfort Okpere, aged 57, who had a fracture of the right femoral head due to an accident and had to use crutches in order to walk. It is claimed that after Prophet Joshua prayed for her, she miraculously laid down her clutches and began to walk unassisted. ${ }^{36}$ Another story of a stupendous healing concerns a certain Mrs Mukhele from Cameroon who had come to the prophet with advanced cancer in her cheek. It is alleged that after Joshua ministered the anointing water for salvation to her and touched her swollen face she smiled testifying that the pain had gone. ${ }^{37}$

\footnotetext{
32 http://suite101.com/article/african-leaders-flock-to-lagos-for salvation-a/17838 accessed on 11/8/2012.

33 http://suited101.com/article/african-leaders-flock, accessed on 6/9/2012. See also

http://articles.onlinenigeria.com/nigerian-churches/4283-synagogue-church-of-all-nati accessed on 14/11/2013.

34 http://suite101.com/article/african-leaders-flock-to-lagos-for salvation-a/17838 accessed on 11/8/2012.

35 http://suite101.com/article/african-leaders-flock-to-lagos-for salvation-a/17838 accessed on 11/8/2012.

36 http://thetbjoshuafanclub.wordpress.com/2010 accessed on 7/9/2012.

37 http://thetbjoshuafanclub.wordpress.com/2010 accessed on 7/9/2012.
} 
Yet another case involves Mr Frank Ebaghelli who was unable to walk due to a fracture of his tibia and fibula. He was brought to the prophet lying face down in his vehicle. Joshua gave a bottle of anointing water for salvation, healing and deliverance to the family members to minister to him. It is claimed that after receiving the water Ebaghelli rose to his feet and walked, to the greater glory of God. ${ }^{38}$

It is also reported that Joyce Banda, now President of Malawi, spent a large part of 2011 visiting Joshua at SCOAN. She had been consulting the prophet since 2009 when her husband suffered a stroke. Joshua healed him by the power of prayer and he recovered his voice which had been lost due to the stroke. ${ }^{39}$

Although these stories lack core medical evidence they seem to attract many people to SCOAN who strongly believe that Joshua has supernatural powers bestowed upon him by God - powers which enable him to heal any kind of disease and meet the spiritual, social, economic and political needs of his clients in sub-Saharan Africa, thereby accounting for the tremendous growth of his church.

\section{TB Joshua's Prophecies as the Strongest Point of his Career}

Apart from Joshua's successes in faith healing, it appears that one of the major factors that have led to huge successes in his ministry is his ability to 'accurately' predict the future. He frequently uses prophecy in the manner in which the $9^{\text {th }}$ century BC prophets, Elijah and Elisha did in ancient Israel. It is always asserted that his prophecies are revealed to him by God and that whatever he predicts always comes to pass. This has made Joshua the most popular 'prophet' in Africa - something that attracts many people to his church today. The internet is full of prophecies, which, it is claimed, were uttered by Joshua and which, apparently, have been 'fulfilled'. Space does not allow us to narrate all the prophecies that have been attributed to Joshua. For the sake of this presentation, we shall select here a few of such prophecies to substantiate our argument in this article.

In the first instance, it is reported that on Sunday, 29 June 2008 Joshua prophesied that an African leader would be rushed out of his country in order to save his soul and that people should pray for him. This prophecy is linked to the late Zambian President, Levy Mwanawasa, who was rushed out of his country on 1 July 2008 to a hospital in Paris, France, to seek medical attention where he died after suffering a stroke. ${ }^{40}$

Besides, it is held that on 26 October 2008 Joshua prophesied that the elections in Ghana would lead to re-voting and recounting. As things turned out, on 3 January 2009 John Atta Mills was announced the winner after a vote which needed to be held three times before a president could be determined. Atta Mills came to the SCOAN after his inauguration to testify that Joshua had given him specific details of his three-round victory, culminating in his victory in January 2009. ${ }^{41}$

In addition to this, it is held that Joshua predicted a coup in one of the French speaking countries in Africa and an attempted assassination on her leader. This prophecy was fulfilled on 19 February 2010 when soldiers stormed the Presidential palace, captured the

\footnotetext{
http://thetbjoshuafanclub.wordpress.com/2010 accessed on 7/9/2012.

http://tumfweko.com/2012/04/10/mtharika-kne accessed on 11/8/2012.

http://www.zimeye.org/7.p=50807 accessed on 6/9/2011.

41 http://www.zimeye.org/7.p=50807 accessed on 6/9/2011.
} 
President and cabinet ministers and seized power in a violent coup in the French speaking republic of Niger. ${ }^{42}$

Another incident connected with Joshua's prophecies was the fate of President Laurent Gbagbo of the Ivory Coast. It is reported that long before the violent election-related crises erupted in November 2010, Joshua declared that Gbagbo was going to lose the elections and that he should cede power to his counterpart Allassane Outtara. It is held that Gbagbo sent emissaries to the SCOAN to request for prayers for his re-election bid. Joshua asked Gbagbo to come in person to SCOAN to learn about the mind of God but he refused to do so. As things turned out, after a six-month struggle to cling to power, Gbagbo was eventually arrested and is now standing trial in the International Criminal Court in The Hague in the Netherlands. ${ }^{43}$

In recent times, what has made Joshua and SCOAN even more popular was the death of Bingu wa Mutharika, the former President of the Republic of Malawi. It is reported that on 5 February 2012 Joshua stated that an African head of state would die of his illness which had been plaguing him for a long time. The prediction was repeated on 18 March and 1 April 2012. Mutharika, aged 78, died suddenly on 6 April 2012 due to cardiac arrest. ${ }^{44}$

\section{TB Joshua's Prophecy vis-a-vis $9^{\text {th }}$ Century BC Prophecy in Ancient Israel}

My research shows that modern features of prophecy, as found in the works of Prophet Joshua, are akin to the prophetic traditions of the $9^{\text {th }}$ century BC prophets in ancient Israel as seen in the prophetic ministries of Elijah and Elisha whose activities are characterised by narratives of popular miracle stories. These narratives bring together real acts of power performed by both Elijah and Elisha. The narratives of these prophets show two aspects of their activities. In the first instance, they show the effect they had on the daily lives of people both within the circle of their prophetic guilds and the ordinary people with whom they came into contact. On the other hand they extend their horizon to include the authoritative figures of the political world of their time outside of Israel.

Elijah and Elisha had the capacity to influence political leaders. They were associated with the political life of their nations and stood poised to provide oracles for their kings. They had political influence, which they were able to exercise on behalf of those in trouble. In the same vein, we see this in the ministry of Prophet Joshua who is consulted by many political leaders in Africa - some openly and others in secret. Apart from this, the $9^{\text {th }}$ century BC prophets cared for the needy. A good example is Prophet Elisha, who helped a rich woman from Shunem to bear a son and when he died Elisha brought him back to life at the request of the mother (2 Kings 4:8-37).This is one of the things that Prophet Joshua does best through his philanthropic works in Nigeria. This links him strongly to the prophetic ministries of Elijah and Elisha. ${ }^{45}$

Fohrer has noted that in popular prophetic tradition of the 9th century BC prophets such as Elisha and Elijah, there was a certain connection between prophecy and magic. The New Penguin English Dictionary has defined magic as the use of means such as charms, rites, incantations or spells believed to have supernatural power over the natural forces. The same

\footnotetext{
42 http://distanceisnotabarrier.wordpress.com/2010 accessed on 2/9/2012.

43 http://www.zimeye.org/7.p=50807 accessed on 6/9/2011.

44 http://www.zimeye.org/7.p=50807 accessed on 6/9/2011. See also http://tumfweko.com/2012/04/10/mtharikakne accessed on 11/8/2012.

45 Fohrer, History, 225
} 
dictionary also adds that magic consists of an extraordinary power of influence, producing surprising results and defying explanation. ${ }^{46}$

In reference to this phenomenon, GW Anderson has noted that in the activities of the prophets there was much that was akin to the world of cultic ideas and practice. He has observed that "as in the ritual drama of the cult the sacred words of the liturgical formula and the acts of the ritual were potent with divine energy, so the words of the prophetic oracle and the actions which have been described as prophetic symbolism or acted prophecy, did not merely describe situations and events but helped to bring them about."47 This shows that there was within the $9^{\text {th }}$ century BC prophets an element of magico-cultic practice whose aim was to manipulate divine power for the furtherance of the aims of individuals or societies (see 2 Kings 4:38-44). ${ }^{48}$

It appears that both Elijah and Elisha displayed, to a certain extent, some magical powers in their prophetic ministry. Incidents such as reviving a dead soul by a ritual action (1 Kings 17:17-24); bringing down rain by supernatural powers (1 Kings 18:41-46); increasing little flour and cooking oil several times (2 Kings 4:1-7); helping a childless woman to bear a son (In 2 Kings 4:8-37); the recovery of someone's axe-blade which fell into the water (2 Kings 6:1-7) and the healing of Naaman (2 Kings 5:1-14) show that the $9^{\text {th }}$ century BC prophets did not hesitate to act as magicians. The same can be said, to a large extent, of Prophet Joshua. Some of his miracle performances look like the work of a magician. Quite often, in order to heal the sick, he makes them fall down on the ground by the gesture of his hand, or touching them, or merely shouting at them. He makes them foam and behave as if they are mad or possessed by evil spirits - all in the name of Jesus. Such spells of power, which defeat logical explanation, resemble the works of a 'magician' in typical African style! ${ }^{49}$

Again, according to Fohrer, the legends of the prophets of the $9^{\text {th }}$ century BC period frequently mention features which are reminiscent of divination. The Collins Concise Dictionary has defined divination as the art or practice of discovering future events or unknown things, as though by supernatural powers. ${ }^{50}$ There are many examples in the prophetic ministry of both Elijah and Elisha which substantiate this point. In the first instance, in 2 Kings 1:2 Elijah saw the imminent death of King Ahaziah. Coupled with this, Elisha knew where water could be found in the desert (2 Kings 3:16-17). He also knew that Gehazi, his servant, was hastening after Naaman to demand some gifts from him (2 Kings 5:25-6). In addition to this, Elisha knew where the Aramean army was laying in ambush (2 Kings 6:9). Elisha also knew that the King had given orders to kill him (2 Kings 6:32). He also knew what the king of Damascus said in his bed chamber (2 Kings 6:12) and finally he knew that the king must die and that Hazael would be his successor (2 Kings 8:10-13). ${ }^{51}$ By most accounts, these are some of the characteristics that are attributed to TB Joshua today as seen in the secret knowledge he had about the death of the late President Chiluba of Zambia and President Binguwa Mutharika of Malawi. It should be noted that as in the case

\footnotetext{
46 The New Penguin English Dictionary, 836.

47 GW Anderson, “The religion of the Israel” in M Black \& HH Rowley (eds.), Peake’s Commentary on the Bible, London: Thomas Nelson and Sons, 1977:164.

48 Anderson, “The religion of Israel”, 164.

49 Personal observation on Emmanuel TV Station, live broadcasting.

50 JM Sinclair (ed.), Collins Concise Dictionary, Glasgow: Harper Collins Publishers, 1999:419.

51 Fohrer, History, 232-233.
} 
of Prophet Joshua, in ancient Israel prophets were expected to make certain predictions according to popular demand, which made them more believable.

It appears that on the basis of the abovementioned discussion, prophecy can and does indeed play a very important role in the growth and development of the Church in subSaharan Africa as seen in the case study of the Synagogue Church of All Nations, founded by Prophet Joshua in his native land, Nigeria. What has made the church so successful is its ability to pick up certain elements in Hebrew prophecy which have strong appeal to the African psyche and are able to fulfil the spiritual, social, economic and political needs of the people of Africa today. Prophet Joshua and his church seem to know what makes the African people tick. They are able to provide African answers to African problems. Such answers may require the use of magic-like supernatural powers as those that were exercised by the $9^{\text {th }}$ century BC prophets in ancient Israel to the great delight of the people for whom they were called to serve.

\section{Concluding Remarks}

In conclusion, I wish to mention that this article has examined the factors that have led to the tremendous growth and expansion of SCOAN in Nigeria. The article began by discussing the nature of prophets and prophecy in ancient Israel. It has made a distinction between two types of prophecy, namely that which is associated mainly with the $9^{\text {th }}$ century BC prophets which placed a great deal of emphasis on magic-like miracles and predicting the future on the one hand, and the $8^{\text {th }}$ century BC prophecy characterised not so much on predicting the future and performance of miracles but on issuing warnings regarding people's moral behaviour and the punishment that may follow for the sins of the people on the other. The article has observed that while the first type of prophecy, as seen in the work of prophets Elijah and Elisha, was very popular, the second type of prophecy was less popular because of its unpalatable message. In the article it has been argued that the prophecy found in the Synagogue Church of All Nations seems to be similar to that of the $9^{\text {th }}$ century BC prophets as seen in its emphasis on miracles of healing and predictions of future events which, apparently, have come to pass. This augurs well with the African psyche which looks for miracles in order to be convinced that people are indeed in the presence of God. The article concludes by noting that, as a result of their deep understanding of the African mind and the spiritual, social, economic and political needs of the African people in modern times, Prophet Joshua and SCOAN have become household names attracting people nationally, regionally and internationally who wish to be associated with the services that they offer to the African people and the international community. 


\section{BIBLIOGRAPHY}

Allen, R 2000. The New Penguin English Dictionary. London: Penguin Books, 836.

Anderson, GW 1977. "The Religion of Israel” in M Black \& HH Rowley (eds.), Peake's Commentary on the Bible. London: Thomas Nelson and Sons.

Dietrich, W 2007. " 1 and 2 Kings” in John Barton \& John Muddiman (eds.), The Oxford Bible Commentary. Oxford: Oxford University Press.

Fohrer, G 1972. History of Israelite Religion. London: SPCK.

Hooke, SH 1977. "The religious institutions of Israel” in Matthew Black \& HH Rowley, Peake's Commentary on the Bible. London: Thomas Nelson \& Sons.

Ramsey, Michael 1977, "The Authority of the Bible” in Matthew Black \& HH Rowley (eds.), Peake's Commentary on the Bible. Middlesex: Thomas Nelson \& Sons.

Sinclair, JM (ed.) 1999. Collins Concise Dictionary. Glasgow: Harper Collins Publishers.

Whybray, RN 1993. "Prophets” in Bruce M. Metzger \& Michael D Coogan (eds.), The Oxford Companion to the Bible. Oxford: Oxford University Press.

\section{Respondents}

Alimi, MM. University of Botswana, Gaborone, Botswana, 13/11/2013

Arua, AE. University of Botswana, Gaborone, Botswana, 13/11/2013.

Ikpe, IB. University of Botswana, Gaborone, Botswana, 4/11/2013

Rakaisa, R. University of Botswana, Gaborone, Botswana, 11/11/2013.

\section{Internet Sources}

http://www.zimeye.org/7.p=50807 accessed on 6/9/2011.

http://tumfweko.com/2012/04/10/mtharika-kne accessed on 11/8/2012.

http://thetbjoshuafanclub.wordpress.com/2010 accessed on 7/9/2012.

http://tumfweko.com/2012/04/10/mtharika-kne accessed on 11/8/2012.

http://distanceisnotabarrier.wordpress.com/2010 accessed on 2/9/2012.

http://suite101.com/article/african-leaders-flock-to-lagos-for salvation-a/17838

accessed on 11/8/2012.

http://www.scoan.org/about/history, accessed on 11/8/2012.

http://.scoan.org/about/prophettb-joshua/biography, accessed on 6/9/2012.

http://www,usatoday.com/news/religion/story/2, accessed on 23/9/2012. 